\title{
Reconsidering Migration, Globalization and Social Conditions in the World System*
}

\author{
Arno Tausch ${ }^{* *}$ \\ Corvinus University, Innsbruck University
}

\begin{abstract}
The present article is based on a 175-nation, 26 standard predictor variables study on the determinants of seven important indicators of social conditions on a global scale. The standard predictors cover all major development accounting theories today, including a) Demographic factors, b) Dependency and world systems approaches, c) Feminist paradigms, d) Geographic factors, e) Human capital formation, f) Integration into the European Union and the European Monetary Union, g) Migration, h) Military expenditures and military personnel rates, i) Neo-liberal approaches, and j) World religious factors. Our indicators of the social conditions relating to our globe include data about 1. Basic human needs satisfaction, 2. Gender inequality, 3. Inequality, 4. Life satisfaction, and 5. Unemployment.

Our seven multiple OLS regressions, based on the SPSS statistical program and international comparative country-level data for the world in 2000 and after, take into account the non-linear trade-offs between development level and subsequent development performance, first associated with the name of the economist Simon Kuznets. They show the importance of migration in comparison to other, widely debated "drivers" and "bottlenecks" of social development. Received worker remittances per GDP have positive effects on life quality (life expectancy, life satisfaction, Happy Life Years), and gender relations (closing the political gender gap; closing the overall gender gap) in the labor exporting economies. There is no significant effect of any migration variable on the unemployment rate. Elements of other, more established approaches also receive qualified support.
\end{abstract}

Keywords: international relations and international political economy, international migration. JEL classification numbers: F5, F22.

\section{Dünya Sisteminde Göç, Küreselleşme ve Toplumsal Koşulları Yeniden Düşünmek}

\section{Özet}

Makale, 175 ülke ve 26 standart kestirim değişkenini kullanarak küresel ölçekte yedi önemli toplumsal koşul göstergesinin belirleyicilerini araştıran bir çalışmaya dayanmaktadır. Standart kestirim değişkenleri kalkınmaya dair var olan bütün temel

\footnotetext{
* The author would like to thank the anonymous reviewers of the journal for their helpful and constructive comments.

** Arno Tausch is Visiting Professor of Economics at Corvinus University, Budapest, and Adjunct Professor of Political Science at Innsbruck University, Austria. E-mail: arno.tausch@uibk.ac.at
} 
teoriyi, özellikle de şunları kapsamaktadır: a) Demografik faktörler, b) Bağımlılık ve dünya sistemi yaklaşımları, c) Feminist paradigmalar, d) Coğrafi faktörler, e) Beşeri sermaye oluşumu, f) Avrupa Birliği ve Avrupa Parasal Birliği’ne entegrasyon, g) Göç, h) Savunma harcamaları ve savunma personeli oranı, i) Neoliberal yaklaşımlar, j) Dünya dinlerine dair faktörler. Dünya çapındaki toplumsal koşullara dair göstergeler şunlar hakkında veri içermektedir: 1.Temel insani ihtiyaçların karşılanması, 2.Toplumsal cinsiyet eşitsizliği, 3. Eşitsizlik, 4. Yaşam memnuniyeti, 5. İşsizlik.

Yedi adet çoklu OLS regresyonu ile, ülke ölçeğinde uluslararası karşılaştırmalı 2000 yılı ve sonrası için veri ve SPSS istatistik programını kullanarak, kalkınma seviyesi ve bunu takip eden kalkınma performansı arasındaki ilk defa iktisatçı Simon Kuznets'in adıyla ilişkilendirilen doğrusal olmayan ödünleşmeyi incelemekteyiz. Analiz, göçün toplumsal kalkınmanın diğer çok tartışılan "etmenleri” ve "darboğazlarına” kıyasla sahip olduğu önemi göstermektedir. İşçi ihraç eden ülkelerde, GSYH başına düşen elde edilen işçi dövizlerinin, yaşam kalitesi (yaşam beklentisi, yaşam memnuniyeti, Mutlu Yaşam Yılları) ve toplumsal cinsiyet ilişkileri (siyasi toplumsal cinsiyet açığının kapatılması, genel toplumsal cinsiyet açığının kapatılması) üzerinde pozitif bir etkisi olduğu ortaya çıkmaktadır. Göçle ilgili herhangi bir değişkenin işsizlik üzerinde istatistiki olarak anlamlı bir etkisi ise bulunmamaktadır. Daha yerleşik yaklaşımlara dair unsurlar da çalışma ile destek bulmaktadırlar.

Anahtar kelimeler: uluslararası ilişkiler ve uluslararası siyasal iktisat, uluslararası göç. JEL siniflamasi: F5, F22.

$\mathrm{T}$ This article compares the predictive power of migration theories on the social conditions in the world system with older, more established approaches in international development accounting. Our empirical results are based on a 175-nation, 26 predictor variables standard OLS (Ordinary Least Squares) regression study. Our predictors cover all major development accounting theories today, including demographic factors, dependency and world systems approaches, feminist paradigms, geographic factors, human capital theories, economic integration theories, military expenditures and military personnel rates, neo-liberal approaches, and world religious factors.

Our indicators of the dependent variables - the social conditions on a global scale - include data about basic human needs, gender inequality, inequality, life satisfaction, and unemployment. In presenting our OLS regressions, we take into account the nonlinear trade-offs between development level and subsequent development performance, first associated with the name of the economist Simon Kuznets.

Our article dramatically shows the importance of migration in comparison to other, widely debated "drivers" and "bottlenecks" of social development. This focus on migration is a new direction in cross-national development accounting research, heretofore dominated by an emphasis on globalization, dependency and world systems explanations of underdevelopment and development.

The rest of this study is organized as follows. In Section 2 the main theories are briefly outlined. Section 3 is devoted to the data and the research design. The main results 
are presented in Section 4, while Section 5 summarizes the study. We hope that the appendices document our results and encourage the international research community to use and test our data and explanations further.

\section{Theories about the Effects of the 'Four Freedoms' and How to Test Their Comparative Influence on the Social Conditions of Countries}

The freedom of movement of labor is part and parcel of the overall process of globalization. The European Union's neoliberal internal market strategy, for example, clearly rests on the freedom of the movement of goods, capital, services and labor, postulated in the European Union primary law as a basic principle of the European Union and the internal market (Tausch and Ghymers, 2007; Guger, Marterbauer, and Walterskirchen, 2004, 2006). But while hundreds of empirical studies exist on such phenomena as "world economic openness," "foreign direct investments" or "multinational corporation penetration" and the development patterns of the host countries in the 1980s, 1990s and beyond, there is less hard-core macro-quantitative evidence on the effects of migration or the globalization of services on the development performance throughout the world.

Our resume of existing development theories will be rather very short and will concentrate on the importance of the factor of "migration," especially since in a recently published article on the pages of this journal (Tausch and Heshmati, 2012) the current state of global growth and development accounting theories was already summarized at length.

While Tausch and Heshmati focused their research results on the determinants of "smart development" (combined indices considering the performance of countries in the fields of democracy, economic growth, gender, human development, research and development, and social cohesion in respective comparison to the ecological footprint consumed by societies to sustain them), the current research effort is devoted to the original country performance (regardless of the energy inputs needed to sustain them) regarding

1. closing the overall gender gap,

2. closing the political gender gap,

3. Happy Life Years,

4. Life Satisfaction (0-10),

5. Life expectancy (years),

6. quintile share - income difference between richest and poorest $20 \%$, and

7. unemployment rate.

So let us recapitulate that dependency and world systems theories culminated in predicting, with Cardoso (1979), the following processes:

- There is a financial and technological penetration by the developed capitalist centers of the countries of the periphery and semi-periphery,

- This produces an unbalanced economic structure both within the peripheral societies and between them and the centers, 
- This leads to limitations on self-sustained growth in the periphery,

- This favors the appearance of specific patterns of class relations, and

- These require modifications in the role of the state to guarantee both the functioning of the economy and the political articulation of a society, which contains within itself, foci of inarticulateness and structural imbalance (Cardoso, 1979; Cardoso and Faletto, 1971).

The possible negative bottlenecks to these approaches (Bornschier and Chase Dunn, 1985, Tausch and Ghymers, 2007) will be low comparative price levels, high foreign savings, the openings of the national economies to free production zones, a low MNC (Multinational Corporations) outward investment presence in the world markets (low MNC headquarter status) and a high MNC PEN - stock of Inward FDI per GDP, as well as a high world economic openness, measured by the export-share per GDP + import-share per GDP.

A vast quantitative literature exists in the fields of political science and sociology, demonstrating the negative effects of globalization on social well being in many different countries, and based on multiple regressions with international standard statistical data.

A number of scholars, like Guger, Marterbauer, and Walterskirchen, (2004, 2006), would quote in this context the 'Kalecki/Steindl paradigm' as well, implying that stagnation tendencies per se are a consequence of oligopolistic structures, independent of whether "capital" is "foreign" or "domestic". Steindl (1952) analyzed the process of increasing concentration of capital and the oligopoly of the market over the long period in the major Western countries and established a relationship between economic stagnation and the growth of oligopoly in advanced capitalist countries. Mahutga and Bandelji, 2008 provided a series of quantitative hard-core empirical sociological investigations that relate income inequality to foreign investment in East Central Europe which was opened up to investment by the global economy after the end of Communism in Eastern Europe in 1989. They found that in East Central Europe, foreign investment has had a robust positive effect on income inequality; i.e. multinational corporations' investments have increased social inequalities, with all the political effects that such conditions might imply.

Box 1 presents a summary of the most important and sometimes conflicting theoretical expectations (articles, dissenting with the dependency/world systems theory consensus are highlighted in indented letters):

\section{Box 1}

\section{Major Studies on Dependency, World System and Social Development by Chronological} Order of Date of Publication

(Bornschier, 1983): integration into the world economy will result in increased income inequality in peripheral countries.

(Crenshaw, 1992): (1) national wealth exhibits a direct, curvilinear relationship with income inequality; (2) world-systems/dependency theory finds less support; and (3) agricultural density, has a robust, negative influence on income inequality. 
(Ragin and Bradshaw, 1992): dependency has a more harmful effect on the physical quality of life than on economic development.

(Wimberley and Bello, 1992): reduction of primary export dependence in Third World countries promotes food consumption, and transnational corporate (TNC) investment dependence has an exceptionally strong harmful effect on food consumption in the periphery.

(Bradshaw, 1993): externally imposed austerity measures have directly or indirectly impeded child survival, childhood immunization, economic growth, prevalence of health attendants, adequate nutrition, and balanced urbanization.

(Crenshaw and Ameen, 1994): strongest support in the explanation of inequality for modernization and ecological-evolutionary theories, while the patterns of support for political redistribution and dependency/world-systems theory are more mixed.

(Shen and Williamson, 1997): Foreign investment and debt dependency have adverse indirect effects on child mortality.

(Wimberley, 1998): effects of foreign investment dependence on the satisfaction of basic human needs in the Third World. Satisfaction of nutritional needs was indicated by per capita calorie and protein consumption. Two forms of investment dependence are measured for 1967: MNC penetration and debt accumulated from bilateral foreign aid. Specific effects of MNC investment in the agricultural sector also were examined.

(Morris, 1999): based on data from two cohorts of countries with data on income inequality (33 countries, 1968-1973, and 31 countries, 1985-1992, respectively. World-system analysis and some aspects of dependency theory are relevant to explaining income inequality both before and after global changes.

(Shen and Williamson, 1999): authors find that women's status, age at first marriage, and reproductive autonomy are strong predictors of maternal mortality. In addition, article finds that economic dependency, especially multinational corporate investment, has a detrimental effect on maternal mortality.

(Kentor, 2001): foreign capital dependence has a positive effect on income inequality, raises fertility rates, accelerates population growth and retards economic development. Trade openness, in contrast, has long-term positive effects on economic development.

(Shen and Williamson, 2001): authors establish that foreign trade, investment, and debt dependency have adverse effects on infant mortality, mediated by variables linked to modernization/free trade theory and gender inequality theory. State strength has a beneficial direct effect on infant mortality decline. Women's education and reproductive autonomy have significant direct effects, but also play important roles as mediating variables, as does the rate of economic growth.

(Alderson and Nielsen, 2002): total inequality variation is principally affected by the percentage of the labor force in agriculture, followed by the institutional factors of union density and de-commodification, and only then by globalization. On the other hand, longitudinal variation in inequality, while still dominated by the percentage of the labor force in agriculture, is also principally affected by aspects of globalization such as developing countries' import penetration and direct investment outflow, and to a lesser extent by migration. Globaliza- 
tion explains the longitudinal trend of increasing inequality that took place within many industrial countries better than it has cross-sectional inequality differences among countries.

(Reuveny and Li, 2003): democracy and trade reduce income inequality, foreign direct investments increase income inequality, and financial capital does not affect income inequality.

(Meyer, 2003): global economic forces reduce occupational sex segregation and inequality. Global economic restructuring is a gendered process that transforms and builds on existing gender inequalities.

(Shandra, Nobles, London, and Williamson, 2004): economic and social modernization has beneficial effects on infant mortality. Multinational corporate penetration fosters higher levels of infant mortality. Interaction effects suggest that the level of political democracy conditions the effects of dependency relationships based upon exports, investments from multinational corporations, and international lending institutions.

(Bussmann, de Soysa, and Oneal, 2005): results indicate that globalization does not increase national income inequality. The ratio of foreign direct investment to gross domestic product is unrelated to the distribution of incomes in both developing and developed countries. The share of income received by the poorest $20 \%$ of society is also is unaffected by foreign investment. Nor are alternative measures of economic openness -- the trade-to-GDP ratio and Sachs and Warner's (1995) measure of free trading policies -- associated with greater income inequality.

(Shandra, Nobles, London, and Williamson, 2005): indicators linked to economic and social modernization have beneficial effects on child mortality. Multinational corporate penetration fosters higher levels of child mortality. Interaction effects suggest that the level of political democracy conditions the effects of dependency relationships based upon multinational corporations.

(Beckfield, 2006): regional integration explains nearly half of the increase in income inequality in the Western European countries. The effects of regional integration on income inequality are the net of several controls, including two established measures of globalization, suggesting that a sociological approach to regional integration adds to our understanding of rising income inequality in Western Europe.

(Moore, Teixeira, and Shiell, 2006): study uses network analysis. Periphery is significantly and positively associated with national-level infant mortality rates.

(Spencer, 2006): study emphasizes (i) the importance of measuring global stratification according to trading patterns and (ii) the strong, negative effects of income inequality on life expectancy among peripheral populations.

(Tsai, 2006): poverty is defined by living below an income of US $\$ 1$ or $\$ 2$ a day. Empirical outcomes reveal that besides a country's income level, tropics, landlockedness, population growth, and secondary schooling opportunity are significant predictors of poverty reduction, whereas political factors (democracy, military spending, and war) and government social spending are only weak predictors. No evidence was found to support the effects of economic openness on poverty, as proposed by the neoliberal school. 
(Lee, Nielsen, and Alderson, 2007): most traditional measures of trade dependence have inconsistent or weak positive effects on inequality, while export commodity concentration has a negative effect. They also find that the effects of foreign direct investment on inequality are positive at low to intermediate levels of government size, but that this effect is substantially attenuated or negative in societies with a larger public sector. Conclude that distributional outcomes are dependent upon how the state reacts to growing globalizationrelated pressures.

(Tsai, 2007): significant positive impacts of political globalization, whereas economic and social globalization do not generate favorable influences when development level and regional differences are operated as controls. The overall globalization index is found to generate expected favorable influence on the overall human development index. Several hypotheses about globalization's potential negative effects through increasing societal instabilities and reducing state power and social spending are not supported in the analysis. It is concluded that globalization identified by increased global flows and exchanges contributes to rather than hampers progress in human welfare.

(Babones, and Zhang, 2008): aggregate trade is not empirically related to income inequality for any panel of countries, and country-level research focusing specifically on 'North-South' trade and national income inequality has generally yielded inconsistent or no significant results. Authors attribute this disconnect between expectations and reality to heterogeneity among the countries typically classified as members of the global 'South.' Authors find that the relationship between inequality and trade is consistently conditioned on the zone of the world-economy over the period 1980-2000.

In dealing with the issue of migration, we first might notice that to our knowledge hardly any theoretically, methodologically or empirically solid cross-national, world level evidence exists about the macro-societal effects of migration on social development - with the laudable exception of Sanderson, 2010, which analyzed the effects of migration on the Human Development Index on a global scale. This fact might be surprising, but is certainly connected to the hitherto existing lack of cross-national, comparative data on global migrations in both the migration sending and the migration recipient countries. Such is needed to support a reasonable, global, cross-national development accounting research design. This lack of world-level cross-national evidence is all the more surprising given the often very conflict-oriented ideological clashes in many migration recipient countries. As Sanderson, 2013 very correctly remarks:

"Investigations into the economic implications of immigration are situated in a gap between two well-developed literatures that have developed largely in parallel to one another, without much cross-dialogue. On the one hand, there is a broad and deep literature on the economic aspects of immigration, including, for example, labor market incorporation [...], discrimination and labor market segmentation [...], labor relations and immigrant social networks in the context of economic restructuring [...], the social organization of labor and socio-economic mobility [...], immigrant entrepreneurship [...], labor market inequality and immigrant earnings [...], social integration and immigrant homeownership rates [...], and unionization and immigrant mo- 
bilization [...]. These studies document, often in rich detail, how immigrant status affects an array of economic outcomes in host countries. However, this literature has not explored the broader, macro-level economic implications of immigration, leaving open the question of how immigration affects aggregate living standards in host countries. On the other hand, there is a large body of macro-comparative research on the cross-national correlates of economic development and development-related outcomes. This research has developed over the past 40 years as the global dispersal of economic production, distribution and exchange has further integrated national economies into international circuits of production and exchange [...], a process now commonly referred to as 'economic globalization'. As economic globalization has broadened and deepened interactions among countries, scholars have increasingly turned away from factors internal to countries and toward global factors to explain cross-national variation in development outcomes. This literature identifies several key global factors, including, most importantly, foreign direct investment (FDI) and international trade [...]. This research, however, has not systematically investigated international migration. Yet, migration is an important component of economic globalization, as the cross-national movement of migrants integrates labor markets and facilitates cross-national exchanges of resources [...]. Thus, just as capital (i.e. FDI) and goods (i.e. trade) cross national boundaries and exert influence on development outcomes, so, too, should labor in the form of international migration. [...]. Thus, while international migration levels increase, and more countries are affected by these flows, the social science literature remains curiously silent on the question of whether or not immigration has long-term consequences for living standards in host countries: cross-national studies of development have largely ignored 'the immigration question' and social science research on the economic aspects of immigration has generally neglected the macrolevel 'development question"' (Sanderson, 2013: 59).

In Tausch and Heshmati, 2012, it was already highlighted that from the 'founding four' of world systems research (Amin, 1994; Arrighi, 1995; Frank, 1967 and 1998; and Wallerstein, 2000), we find relatively pessimistic migration statements. By contrast, neoliberal economists like Jeffrey Williamson (2002) came to the conclusion that real wages and living standards converged among the currently-industrialized countries due to migration. Emigration may contribute to labor scarcity, but it also lowers the GDP. Historical, $19^{\text {th }}$ century income convergence was driven primarily by the erosion of the gap between the New World and the Old. In addition, many poor European countries were catching up with the industrial leaders. The labor force impact of migrations on each member of the Atlantic economy in 1910 varied greatly. Among receiving countries, Argentina's labor force was augmented most by immigration (86\%), Brazil's the least (4\%), with the United States in between (24\%). Among sending countries, Ireland's labor force was diminished most by emigration (45\%), France the least (1\%), with Britain in between (11\%). At the same time, the economic gaps between rich and poor countries diminished. Real wage dispersion in the Atlantic economy declined between 1870 and 1910 by $28 \%$, GDP per capita dispersion declined by $18 \%$ and GDP per worker dispersion declined by $29 \%$. Migration affects equilibrium output, wages and 
living standards by influencing aggregate labor supply. Emigration is estimated to have raised Irish wages by $32 \%$, Italian wages by $28 \%$ and Norwegian by $10 \%$. Immigration is estimated to have lowered Argentine wages by $22 \%$, Australian by $15 \%$, Canadian by $16 \%$, and American by $8 \%$ (Williamson, 2002). Most liberal and left-of-center-oriented global political discourse would expect that worker remittances have beneficial effects for the sending countries, and that they amount to a huge transfer machine of wealth from the rich, migration recipient countries to the poor, migration sending countries.

\section{Migration is thus seen by many as a win-win situation.}

The UNDP Human Development Report (2009), which provided world scholarship with a first real set of comparative, global migration data, maintained that a doubling of per capita income from US $\$ 1,000$ to $\$ 2,000$ (about equivalent to the East and Southeast Asian per capita income level in 1960 and its growth rate between 1960 and 1985, 3.4\%) increases the emigration rate by $12 \%$. In contrast, an increase for today's middle-income country from $\$ 10,000$ to $\$ 11,000$ has a negligible effect on the emigration rate $(0.03 \%)$. The UNDP HDR (2009) also maintains that financial remittances are vital in improving the livelihoods of millions of people in developing countries. There is a positive contribution of international remittances to household welfare, nutrition, food, health and living conditions in places of origin (UNDP HDR, 2009: 72).

Apart from globalization, dependency and world systems theories, the question of the geographic, demographic and other independent variables in development accounting found much more attention in the economic than in the sociological and political science literature (See Ciccone and Jarocinski, 2008; Gylfason, 2001; Hodler, 2004; Sachs and Warner, 2001; and Sturm and de Haan, 2005). According to the research (Ciccone and Jarocinski, 2008; Sala-i-Martin, Doppelhofer and Miller, 2004; and Sturm and de Haan, 2005), we currently are facing around 100 popular independent variables in the current econometric literature on the determinants of economic growth. In their American Economic Review article (2004), Sala-i-Martin and associates highlight the point that the strongest effects on growth are found for good primary schooling enrolment, the low price of investment goods and a low initial level of income where the latter reflects the concept of conditional convergence. Other important variables include regional dummies (East Asia, Sub- Saharan Africa, or Latin America), some measures of human capital and health (life expectancy, proportion of a country in the tropics, and malaria prevalence), religious dummies, and some sectorial variables such as mining. Interestingly enough, and in contradiction to Huntington (1996), Sala-i-Martin and his team even found quite strong and positive effects of the predominance of the Islamic faith on economic growth, with a likewise positive effect of Buddhist and Confucian cultures on economic growth, while the initial income levels and government consumption levels also quite strongly affected the growth rate. Beyond the culturalism inherent in Huntington (1996), we maintain with Sala-i-Martin (2004) and Inglehart and Norris (2003) that indicators relating to "Muslim culture" may have many different positive and negative effects on different processes of "development," with a lower rate of societal income inequality in Muslim societies due to Zakat/Zekat-related wealth taxes being a prominent example. 


\section{Presenting the Data and Developing the Research Design}

To start with, we have made our data completely and freely available on the Internet so that the global research community can access it and check our results or conduct new research (http://www.hichemkaroui.com/?p=2017 and http://www.uni-corvinus. hu/index.php?id=14767\#c38860).

The internet site http://www.hichemkaroui.com/?p=2017 contains not only the Microsoft EXCEL data (there: Table 1 of the EXCEL file) and a list of the sources (there: Table 2 of the EXCEL file), but also a codebook and a data and source description in pdf format.

Our investigation duly acknowledges many of the key determinants of economic growth mentioned in the economic literature, like current shares of the country's inhabitants in total world population, calculated from UNDP data; the famous Heritage Foundation 2000 Economic Freedom Score; absolute geographical latitude, adapted from Easterly's growth theory; (Easterly, 2000 and 2002); the UNDP figures for longterm annual population growth rate, 1975-2005 (\%); the trade-off between development level and development performance, otherwise also known in economics as 'conditional convergence' (natural logarithm GDP per capita; natural logarithm GDP per capita ^2); the simple Huntingtonian fact of whether a country is Muslim, to be measured by membership in the Organization of Islamic Cooperation (OIC) or by Muslim population share (Nationmaster); UNDP data on population density (based on the CIA's World Factbook); UNDP data on public education expenditure per GDP; and the UNDP education index, combining the enrollment rates at the primary, secondary and tertiary education levels. We also take into account UNDP figures on military expenditures per GDP and the openly available CIA data on the military personnel rate, which are key variables of contemporary political science international relations theory and peace research. In our analysis, we also recognize the theoretical and practical (political) potential of migration and European (Monetary) Union membership.

Weeding out the relevant from the irrelevant predictors is a well-known problem of international development accounting. Unfortunately, the communication between the discipline of sociological and political science theories of economic growth and development and the discipline of economics de facto is not well established. As an example it is worth mentioning that not a single essay mentioning the catch-words " $M N C$ penetration" and "economic growth" was ever published throughout the period of the entire and intensive debate on the effects of "foreign capital penetration" on economic growth from the late 1970s to the present in a leading journal of the global economics profession such as the "American Economic Review." Instead of concentrating, as sociologists do nowadays, on the ever more complex modeling of the effects of "foreign capital dependence," the economics profession by contrast, developed its mathematical models side by side with an ever-growing amount of many different variables, which 
featured as 'control variables' in the literature. An attempt, like the one by Sala-i-Martin (1997), to filter out the most robust predictors of economic growth by applying Bayesian techniques and combining dozens of predictor variables in all mathematically possible different combinations is a legitimate one from the viewpoint of the advancement of social science and statistical methodology. By contrast, sociologists used to the published articles in journals like the American Sociological Review most probably would be shocked by Sala-i-Martin's successful attempt to run two million regressions (in a scientific paper version of his 1997 essay, he even speaks about four million regressions), brought about by endless possible combinations of dozens of possible predictor variables of economic growth. Availability of computer power, common databases and search engines with on-line journal services may finally bring the three disciplines of sociology, political science and economics closer.

The problem which led Sala-i-Martin to perform his millions of regressions exists and remains unresolved indeed. The fact that independent variable $\mathrm{x} 1$ is significantly determining the dependent variable $y$, the growth rate, or for that matter, income inequality, infant mortality, or whatever under the inclusion of predictors or conditional variables $\mathrm{x} 2$ and $\mathrm{x} 3$, but losing the statistical significance when variable $\mathrm{x} 4$ is included in the regression, is all too well known in the empirical literature and is a relevant statistical problem indeed. With a few exceptions, empirical sociology and political science have not yet provided a coherent and reliable answer to these problems of correlation and confounded effects. The application of Kohonen's self-organizing maps for selecting the relevant predictor variables, another advance in the methodological literature, is only at the beginning of its application in the field. The methodology has been first attempted by Mostafa and associates in his papers, all published in 2010. Additional applications are required to assess its performance and robustness concerning the limitations, mentioned above.

Touching upon the relationship of this kind of literature to the traditions in economics, we may summarize with Crowly, Rauch, Seagrave and Smith, 1998:

"For more than two decades, economists and sociologists have pursued parallel cross-national quantitative investigations of the determinants of economic development. These investigations have proceeded in mutual ignorance despite the often large overlap in statistical methods and data employed. Apparently contradictory findings have resulted, especially regarding the impacts of international trade and foreign direct investment" (Crowly et al., 1998: 30).

The choice of a country to be included in the final analysis (175 countries) was determined by the availability of fairly good data series for these independent variables (if not mentioned otherwise, UNDP data for the middle of the first decade of the new millennium). In each regression, we use Ln GDP per capita and Ln GDP per capita ${ }^{\wedge} 2$ as an independent variable to take account of the Kuznets curve. As to the independent variables of this study, we mention the following theoretical connections in Box 2: 
Box 2

Paradigms and the Independent Variables of Our Analysis

\section{Demographic factors}

$\%$ world population

Annual population growth rate, $1975-2005 \%$

Population density

Dependency and world systems approaches

Comparative price levels (US $=1.00$ )

Foreign savings rate

FPZ (free production zones) employment as $\%$ of total population

MNC outward investments (stock) per GDP

MNC PEN - stock of Inward FDI per GDP

MNC PEN: DYN MNC PEN 1995-2005

Openness-Index, 1990 (export-share per GDP + import-share per GDP)

Feminist paradigms

$\%$ women in government, all levels

\section{Geographic factors}

Absolute latitude

\section{Human capital formation}

Public education expenditure per GNP

UNDP education index

Integration into the European Union and the European Monetary Union

Years of membership in the EU, 2010

Years of membership in EMU (European Monetary Union), 2010

\section{Migration}

Worker remittance inflows as \% of GDP

Immigration - Share of population 2005 (\%)

Net international migration rate, 2005-2010

Military expenditures and military personnel rates

Military expenditures per GDP

Military personnel rate $\ln (\mathrm{MPR}+1)$

Neo-liberal approaches

2000 Economic Freedom Score

Comparative price levels (US=1.00)

Openness-Index, 1990 (export-share per GDP + import-share per GDP)

World religious factors

Membership in the Islamic Cooperation

Muslim population share per total population 
The statistical design of our study was then based on the usual, SPSS XX ordinary least square standard regression analysis of the 'kitchen sink type' (Durlauf et al., 2008) of economic growth and economic, social and political performance in the research tradition of Barro (2003). To our knowledge, the term "kitchen sink regression," commonly used in econometrics of economic growth, was re-introduced in standard social science journal vocabulary in Laver and Shepsle, 1999. A kitchen sink regression first enters all predictors, mentioned in the literature into a provisional stepwise regression; the final forward regression procedure is then the outcome of regression calculations only with the predictors which survived the prior test of the stepwise regression process with all the predictor variables. Like a real kitchen sink, these variables remain "in the filter," after the "water" of the superfluous variables went "down the sink."

Surveying the vast econometric literature on the subject of the possible drivers and bottlenecks of the overall development performance of a given country, one indeed finds support for the inclusion of geographic and demographic variables in the comparative analysis of development success or failure (see Barro and Sala-i-Martin, 2003; Barro, 1991,1996, 1998; Bloom and Sachs, 1998; Chanda and Putterman, 2007; Dowrick and Quiggin, 1997; Easterly and Levine, 1997; Frankel and Romer, 1999; Gallup and Sachs, 1999; Grier and Tullock, 1989; Hall and Jones, 1999; Kamarck, 1976; Kormendi and Meguire, 1985; Levine and Renelt, 1992; Mankiw, Romer and Weil, 1992; and Rodriguez and Rodrik, 1999).

The main dependent variables for this analysis also correspond to standard knowledge in comparative political science and sociology. An ever-growing number of more recently published investigations not only looked into the effects of MNC penetration on economic growth, but also into the social and also ecological conditions in general (Beckfield, 2006, de Soysa and Neumayer, 2005; Jenkins and Scanlan, 2001; Jorgenson, 2004, 2009; Jorgenson and Burns, 2004; Kentor 2001; Kentor and Boswell, 2003; Lee, 2005;Li and Resnick, 2003; Meyer, 2003; Reuveny and Thompson, 2004; Richards, Gelleny and Sacko, 2001; Shandra, London and Williamson, 2003; Sumner, 2005).

\section{The Role of the 'Fourth Freedom' (Migration) in Redistributing Global Wealth}

We will now present an overview of the statistical overall quality of the main results of our multiple regression analyses in Table 1 . In our view, the detailed regression results, presented in the Appendix 1 of this work, present the best available choice of variables from both theoretical as well as empirical statistical perspectives. In testing the implications of the competing paradigms, we arrive at the following list of multiple regressions with significant statistical results: 
Table 1

The Properties of the Statistical Investigations

\begin{tabular}{l|l|l|l|l}
\hline Dependent variables & adj. R^2 & df. & F-test value & $\begin{array}{l}\text { error probability of } \\
\text { the entire equation }\end{array}$ \\
\hline Happy Life Years & 0.771 & 102 & 86.653 & 0.000 \\
\hline Life expectancy (years) & 0.748 & 105 & 63.293 & 0.000 \\
\hline Life Satisfaction (0-10) & 0.694 & 113 & 64.990 & 0.000 \\
\hline closing overall gender gap & 0.587 & 109 & 26.796 & 0.000 \\
\hline unemployment rate & 0.354 & 103 & 10.416 & 0.000 \\
\hline $\begin{array}{l}\text { quintile share income difference } \\
\text { between richest and poorest 20\% }\end{array}$ & 0.255 & 119 & 6.098 & 0.000 \\
\hline closing the political gender gap & 0.249 & 113 & 7.243 & 0.000 \\
\hline
\end{tabular}

In evaluating our results, we only concentrate on the migration policy variables. These are the variables which received too little attention in cross-national sociological and political science development accounting research, compared to the attention given in earlier such studies to the diverse demographic factors, dependency and world systems approaches, feminist paradigms, geographic factors, human capital formation, the integration into the European Union and the European Monetary Union, military expenditures and military personnel rates, neo-liberal approaches, and world religious factors ever since the debates started by Huntington in 1996. In the Appendix Table $1 \mathrm{~b}$ in the already referred-to study by Tausch and Heshmati (2012) on the pages of this journal, readers were already being referred to the dozens of variables used in the different studies of global development accounting to support or reject different paradigms mentioned.

So what are the effects of migration on social development performance? Talking about significance, we distinguish the usual levels of significance, defined by $* \mathrm{p}<.05$; $* * \mathrm{p}<0.01 ; * * * \mathrm{p}<.001$, and levels of "significance" slightly above these strict limits up to an error probability of $10 \%$. In our results tables in Appendix 1 we highlight the results suggested by a strict interpretation of statistical procedures by the usual asterix $(* \mathrm{p}<.05 ; * * \mathrm{p}<0.01 ; * * * \mathrm{p}<.001)$ while we also permit our readers to make their own judgments by quoting all SPSS XX results for all error probabilities for each predictor variable in our Appendix Table 1.

In Appendix Table 2 we highlight the sources and the data availability for the statistical data, used in this article.

In Appendix 3, we present the correlation matrix between the 26 original predictor variables to address the possible problems of collinearity between the predictors. Following Gupta (2000), we highlight the fact that only the Kuznets curve variables, ln GDP per capita and (ln GDP per capita) 2 , and the two world political dimensions (membership in the European Union and membership in the European Monetary Union; and membership in the Organization of Islamic Cooperation and percentage of Muslims per total population) present Pearson-Bravais correlations among themselves which are equal or larger than the usual threshold of +-.800 . All other correlations between the 
predictor variables are below that threshold. Ever since Jackman (1982), an interesting methodology to treat the problem of higher collinearities which might occur especially in the formulation of the Kuznets curve, has been sometimes used in cross-national development research. It first subtracts the mean natural logarithm of the sample from the country specific natural logarithm of GDP per capita and GDP per capita square respectively and arrives at regression results where the standardized regression coefficients (beta-weights) are then lower than 1.0. But while the mathematical and statistical elegance of such a procedure is recognized, it has to be emphasized that for all practical purposes results do not change much whether one follows Jackman's advice (1982) or one uses the straightforward conventional formulations of the Kuznets curve based on ln GDP per capita and (ln GDP per capita) ${ }^{\wedge} 2$, used in most of the published research on the subject.

Worker remittances have a significant positive effect on life expectancy (years), closing the political gender gap, life satisfaction (0-10), closing the overall gender gap, and Happy Life Years. In order to be able to compare the results for worker remittances with the other migration policy variables, we would have to multiply the results by a factor of minus 1 in order to make them comparable with the results about inward immigration.

The consensus of a large and ever-growing tradition of research would tend to see the effects of international migration on the recipient countries in very positive terms, the political noise from migra-phobic politicians to the contrary. However, not all of the optimistic forecasts of this liberal school of thought can be maintained empirically or at least on a 1:1 basis. We already hinted at the fact that we can assume from the effects of worker remittances that the import of labor has-ceteris paribus - detrimental effects on life quality (Happy Planet Index, life expectancy, life satisfaction, Happy Life Years), and gender relations (closing the political gender gap; closing the overall gender gap). Inward migration increases the competition for jobs on the labor market, and the availability of large numbers of younger male immigrants especially marginalizes women. In the labor export economies, the reverse process happens, with women benefiting from the new shortages on the labor market brought about by outward migration. Supporting this contention, we also have to observe that our cross-national results suggest that the percentage of the population with what today is called an 'immigration background' also has - ceteris paribus - a negative effect on the closing of the political gender gap in the countries of the world system.

To judge by our results, there are also countervailing forces at work, which clearly would suggest to us to distinguish between stock data and flow data of migration. Contrary to what intuition might suggest in the first place, a large share of people with a migration background per total population seems to coincide with a weakening of the role of traditional, local, native elites, and overall income inequality tends to be lower when the share of population with a migration background is higher per total population in a given country. Our results would suggest then that in the migration recipient countries, gender cleavages in income rise, while other, non-gender related income differences fall. 
As we already said, in the comparative social sciences, stock data need not necessarily and always coincide with the patterns of associations of flow data in the empirical analysis. Net international migration rates, 2005-2010, a typical migration flow measure relating to current and contemporary migration flows, are significantly and positively influencing the ratio of the closing of the political gender gap. While stocks of already existing large-scale migrant populations negatively affect the closing of the gender political gap to the tune of -0.225 , which is significant at the $2.6 \%$ level, new inflows, which are best measured by the net international migration rate, positively affect the closing of the political gender gap to the tune of 0.208 , which is not significant at the $5 \%$ level, but would be significant at the $8.3 \%$ level. Certainly, more detailed research would have to establish whether these results can be partially explained by different and shifting cohorts of migrant populations or by profound value changes in the migration sending and migration recipient countries. It cannot be excluded out of hand that second and third generation immigrants in Western countries are more "value conservative" than the first "guest worker" generation had been, and that this explains the obvious differences in the effects of the two migration policy variables on political gender equality.

To look at each of our seven equations in more detail, we begin with the determinants of closing of the overall gender gap based on the World Economic Forum (WEF) data series relative to the 110 countries with complete statistical data. Our equation explains $58.7 \%$ of the total variance, the F-value is 26.796 , and the error probability of the entire equation is 0.000 . All predictors, including the constant, are statistically significant. The constant has a numerically positive sign. The major drivers of gender equality, as measured by the WEF data series, are the percentage of women in government at all levels, modernization (natural logarithm of GDP per capita) and modernity (the squared natural logarithm of GDP per capita), and worker remittances per GDP. We already mentioned that this is a clear sign that the scarcity of labor in the migration sending countries positively affects the chances of women gaining advantages, while at the same time our results imply a worsening situation in the migration recipient countries, where the influx of labor from poorer parts of the world economy leads towards a relative marginalization of female labor. Above, we already mentioned that beyond the culturalism inherent in Huntington (1996), we maintain with Sala-i-Martin (2004) and Inglehart and Norris (2003) that indicators relating to "Muslim culture" may have many different positive and negative effects on different processes of "development". Inglehart and Norris (2003) were correct in maintaining that the "real clash" of "civilizations" is not about economic or social issues per se, but about gender issues. Other bottlenecks against the closing of the gender gap are militarization (military personnel rate) and the share of Muslim population per total population, underlining the negative gender policy trade-off in several Muslim countries, as already predicted by Inglehart and Norris (2003).

Our second equation about the determinants of gender gaps, closing the political gender gap, is also based on the World Economic Forum (WEF) data series and uses the 114 countries with complete statistical data. The results are similar to the ones de- 
scribed above. Our equation explains $24.9 \%$ of the total variance: the F-value is 7.243 , and the error probability of the entire equation is 0.000 . All predictors, including the constant, are significant. The constant has a numerically positive sign. Modernization again worsens the conditions of political gender equality, and modernity increases it. We find worker remittances per GDP among the other significant drivers of political gender equality as measured by the WEF data series. This is again a clear sign that the scarcity of labor in migration sending countries also positively affects the chances of women gaining political advantages, while at the same time our results imply again a worsening political marginalization of women in the migration recipient countries where the influx of labor from poorer parts of the world economy leads toward a relative marginalization of feminist politics and female political participation. Other bottlenecks against the closing of the political gender gap are the membership of a country in the Organization of the Islamic Cooperation, again underlining the negative gender policy trade-off in several existing Muslim countries, as already predicted by Inglehart and Norris (2003), and the overall share (=stocks) of immigrant population per total population. At the same time fresh inflows of migrant population significantly alleviate the situation. With rising educational levels and progressing democratization in many labor export countries around the globe, gender policy values in the countries of Africa, Asia and Latin America change as well.

Our following analyses deal with the indicator series of the Happy Planet Organization and the Global Footprint Network, and all feature a new, ecologically viable understanding of the development process. Our first calculation about the drivers of and the bottlenecks against the Happy Planet Organization development performance indicators is our equation about Happy Life Years, which is based on the 103 countries with complete data: with them the $\mathrm{R}^{\wedge} 2$ is $77.1 \%$, the F-value is 86.653 , and the error probability of the entire equation is 0.000 . All predictors, including the constant, are significant; the numerical sign of the constant is negative. Again, there is the clear Kuznets-curve at work, with modernization increasing, and modernity decreasing the Happy Life Years performance. Again worker remittances significantly enhance, and military expenditures significantly reduce the Happy Life Years performance. Our equation shows that outward migration increases, while inward migration decreases Happy Life Years performance.

Our next calculation about the drivers of and the bottlenecks against the Happy Planet Organization development indicators concerns Life Satisfaction and is based on the 114 countries with complete data: here the $\mathrm{R}^{\wedge} 2$ is $69.4 \%$, the F-value is 64.990 , and the error probability of the entire equation is 0.000 . All predictors, except modernity, are significant; the numerical sign of the constant is negative. Only the first part of the Kuznets-curve is significant. Modernization increases Life Satisfaction performance. Absolute latitude and thus lack of daily and yearly sunshine intensity decrease, and worker remittances significantly enhance Life Satisfaction performance. Our equation shows that outward migration clearly increases, while inward migration decreases Life Satisfaction. 
The equation for the determination of life expectancy was calculated for 106 countries with complete data. The $\mathrm{R}^{\wedge} 2$ is $74.8 \%$, the F-value is 63.293 , and the error probability for the entire equation is 0.000 . All predictors, including the constant, are significant. The numerical sign of the constant is negative. Modernity, lamentably, reduces life expectancy, while modernization increases it. The public education expenditure effort by the government crowds out health, and overall income inequality - as correctly predicted by the public health researchers Wilkinson and Picket, 2006 - reduces life expectancy, too. Worker remittances are an important driver of life expectancy, which implies that migration sending countries benefit socially from the migration process.

The equation for the determination of income inequality was calculated for 120 countries with complete data. The $\mathrm{R}^{\wedge} 2$ is $25.5 \%$, the F-value is 6.098 , and the error probability for the entire equation is 0.000 . All predictors, except the Kuznets curve and the constant, are significant. The numerical sign of the constant is negative. Annual population growth, the foreign savings rate and MNC penetration increase income inequality, while high comparative price levels and a large share of migration stock reduce income inequality. The functioning social welfare institutions of Muslim communities also significantly reduce income inequality rates, mainly due to the mechanisms of the Zakat/Zekat wealth taxes of $2.5 \%$ annually.

The equation for the determination of unemployment was calculated for 104 countries with complete data. The $\mathrm{R}^{\wedge} 2$ is $35.4 \%$, the F-value is 10.416 , and the error probability for the entire equation is 0.000 . All predictors, including the constant, are significant. The numerical sign of the constant is negative. Modernization increases unemployment, while modernity reduces it. The public education expenditure effort by the government crowds out employment. The U.S. economist James Galbraith (Galbraith, 1999, 2007, 2009) was correct in predicting that inequality increases unemployment. Foreign savings increase unemployment. The Muslim population share is statistically associated with a higher rate of unemployment.

\section{Conclusions}

The European debate hardly ever evaluated, from a rational, quantitative and comparative perspective, the current global balance sheet of advantages and disadvantages of the four freedoms of goods, capital, labor and services. For Commission President Barroso, Europe's openness is a 'congenital condition' (http://europa.eu/rapid/pressrelease_SPEECH-07-293_en.htm) .

Our detailed studies based on seven multiple regressions, confirmed some parts of the globalization critical paradigm:

- High comparative price levels, and hence, implicitly, a high level of services of general interest, are a good and sound precondition for leveling the income differences between rich and poor.

- apprehensions of globalization critical research are vindicated by the significant effects of the foreign savings rate. High foreign savings are indeed a driver of unemployment and income inequality.

- MNC penetration increases income polarization. 
We found however that the understanding of the globalization critical research of migration processes was hitherto rather deficient. We can reasonably assume that the import of labor to the centers of the world economy, measured by the reciprocal value of the worker remittances, scale has - ceteris paribus - detrimental effects on life quality (Happy Planet Index, life expectancy, life satisfaction, Happy Life Years), and gender relations (closing the political gender gap; closing the overall gender gap). The percentage of the population with what today is called an 'immigration background' also has - ceteris paribus - a negative effect on political gender justice.

However, on balance other effects also tend to tend to confirm the migration policy liberal consensus as inherent in the UNDP HDR 2009 analysis. There are not only negative messages for inward migration, but the process is a very contradictory one. The share of people with a so-called migration background per total population seems to coincide with a weakening of the role of traditional, local, native elites, and income inequality tends to be lower when the share of population with a migration background is higher per total population in a given country. There is no significant effect of any migration variable on the unemployment rate. Net international migration rates 20052010, which are a typical migration flow measure relating to current and contemporary migration flows, significantly close the political gender gap.

There is also a positive trade-off of effective demand on development. High inequality rates must be regarded in their own right as blockades against life expectancies. With Galbraith (1999, 2007, and 2009) we diagnose such an empirical effect for employment as well: the higher the inequality rate, the higher the unemployment rate.

As correctly predicted by the dependency literature, social polarization is increased by a development model based on a very high foreign capital penetration. One further important consequence of this analysis is the re-discovery of the issue of European industrial policy whose absence determines at the end of the day the high European coefficients of MNC penetration. Thus the old critical questions addressed in the direction of neo-classical theory by such economists as Furtado (1983), Kalecki (1971), Myrdal (1957), Perroux (1983), Prebisch (1988), Rosenstein-Rodan (1964), Rothschild (1995), Seers (1981), and Singer(1975) can be taken up anew.

But certainly, mass migration now re-distributes global wealth, and contributes to several imbalances, including gender imbalances, in the rich countries of our globe. This is our most important qualification of world system and dependency theories today.

\section{References}

Alderson, A.S. and Nielsen, F. (2002). "Globalization and the Great U-turn: Income Inequality Trends in 16 OECD Countries," American Journal of Sociology, 107(5): 1244-1299.

Amin, S. (1994). Re-reading the Postwar Period: An Intellectual Itinerary [M. Wolfers (trans.)]. New York: Monthly Review Press.

Arrighi, G. (1995). The Long 20th Century. Money, Power, and the Origins of Our Times. London, New York: Verso. 
Babones, S. and Zhang, X. (2008). "Heterogeneity in the Global South in the Relationship between Income Inequality and Foreign Trade," International Review of Modern Sociology, 34(1): 95-108.

Barro, R.J. (1991). "Economic Growth in a Cross Section of Countries," Quarterly Journal of Economics, 106(2): 407-43.

------, (1996). "Democracy and Growth," Journal of Economic Growth, 1(1): 1-27.

------, (1998). Determinants of Economic Growth: A Cross-country Empirical Study (First Edition). Lionel Robbins Lectures. Cambridge, MA: MIT Press.

------, (2003). "Economic Growth in a Cross Section of Countries," International Library of Critical Writings in Economics, 159(1): 350-386.

Barro, R.J. and Lee, J-W. (2000). "International Data on Educational Attainment: Updates and Implications," Centre for International Development at Harvard University, CID Working Paper (42).

Barro, R.J. and Sala-i-Martin, X. (2003). Economic Growth (2nd Edition). Cambridge, MA: MIT Press.

Beckfield, J. (2006). "European Integration and Income Inequality," American Sociological Review, 71(6): 964-985.

Bloom, D.E. and Sachs, J.D. (1998). "Geography, Demography and Growth in Africa," Brookings Papers on Economic Activity, 2: 207-295.

Bornschier, V. (1983). "World Economy, Level Development and Income Distribution: An Integration of Different Approaches to the Explanation of Income Inequality," World Development, 11(1): 11-20.

Bornschier, V. and Chase-Dunn, Ch.K (1985). Transnational Corporations and Underdevelopment. New York: Praeger.

Bradshaw, Y.W. (1993). "Borrowing against the Future. Children and Third-world Indebtedness," Social Forces, 71(3): 629-656.

Bradshaw, Y.W. and Schafer, J. (2000). "Urbanization and Development: The Emergence of International Nongovernmental Organizations Amid Declining States," Sociological Perspectives, 43(1): 97-116.

Bussmann, M., de Soysa, I., and Oneal, J.R. (2005). "The Effect of Globalization on National Income Inequality," Comparative Sociology, 4(3/4): 285-312.

Cardoso, F.H. (1979). Development under Fire. Mexico D.F.: Instituto Latinoamericano de Estudios Transnacionales, DEE/D/24 i, Mayo (Mexico (20 D.F., Apartado 85 - 025).

Cardoso, F.H. and Faletto, E. (1971). Dependencia y Desarrollo en América (Dependency and Development in Latin America.) Mexico D.F.: Editorial Siglo I. University of California Press, (C1979.

Chanda, A. and Putterman, L. (2007). "Early Starts, Reversals and Catch-up in the Process of Economic Development," Scandinavian Journal of Economics, 109(2): 387-413.

Ciccone, A. and Jarocinski, M. (2008). “Determinants of Economic Growth. Will Data Tell? ” Working Paper Series, European Central Bank, No 852 / January. Available [online] at: http://www.ecb.int/ $\mathrm{pub} / \mathrm{pdf} / \mathrm{scpwps} / \mathrm{ecbwp} 852 . \mathrm{pdf}$

Clark, R. (2008). "Dependency, Network Integration, and Development," Sociological Perspectives, 51(3): 629-648.

Clauss, G. and Ebner, H. (1978). Grundlagen der Statistik. Fuer Psychologen, Paedagogen und Soziologen. Berlin: Volk and Wissen

Coleman, J.S. (1965). Education and Political Development. Princeton: Princeton University Press. 
Crenshaw, E. (1992). "Cross-national Determinants of Income Inequality: A Replication and Extension Using Ecological-Evolutionary Theory," Social Forces, 71(2): 339-63.

Crenshaw, E. and Ameen, A. (1994). "The Distribution of Income Across National Populations: Testing Multiple Paradigms," Social Science Research, 23(1): 1-22.

Crowly, A.M.; Rauch, J, Seagrave, S., and Smith, D.A. (1998). "Quantitative Cross-national Studies of Economic Development: A Comparison of the Economics and Sociology Literatures," Studies in Comparative International Development, 33(2): 30-58.

de Soysa, I. and Neumayer E. (2005). "False Prophet, or Genuine Savior? Assessing the Effects of Economic Openness on Sustainable Development, 1980-99," International Organization, 59(3): 731-772.

de Soysa, I. and Oneal, J. (1999). "Boon or Bane? Reassessing the Productivity of Foreign Direct Investment," American Sociological Review, 64(3): 766-782.

Delors, J. and Delors C. (1992). Our Europe: The Community and National Development [B. Pearce (trans.)]. London; New York: Verso.

Dowrick, S. and Quiggin, J. (1997). "Convergence in GDP and Living Standards: A Revealed Preference Approach," American Economic Review, 67(1): 41-64.

Durlauf, St. N., Kourtellos, A., and Tan, Ch. M. (2008). “Are any Growth Theories Robust?” The Economic Journal, 118(1): 329-346.

Easterly, W. (2000). “The Middle Class Consensus and Economic Development.” World Bank Policy Research Working Paper No. 2346, May.

Available [online] at SSRN: http://ssrn.com/abstract=630718. Data available [online] at: http://www. cgdev.org/doc/expert\%20pages/easterly/easterly_consensusdata.xls in EXCEL-format. The data are also still retrievable by a Google search, using the search profile words easterly_consensusdata.xls.

Easterly, W. (2002). "Inequality does Cause Underdevelopment: New Evidence," Center for Global Development, Working Paper 1, January. Available (online) at: http://www.cgdev.org/wp/cgd_ wp001_rev.pdf.

Easterly, W. and Levine, R. (1997). "Africa's Growth Tragedy: Policies and Ethnic Divisions," Quarterly Journal of Economics, 112(4): 1203-1250.

European Commission (2005). A New Start for the Lisbon Strategy. Available [online] at: http:// europa.eu.int/growthandjobs/index_en.htm.

-----, (2005 Report): The Economic Costs of Non-Lisbon. A Survey of the Literature on the Economic Impact of Lisbon-type reforms, SEC (2005) 385 (15 March). Available [online] at: http://europa.eu.int/ growthandjobs/pdf/SEC2005_385_en.pdf.

, (2007). Growing Regions, Growing Europe. Fourth Report on Economic and Social Cohesion. Available [online] at: http://ec.europa.eu/regional_policy/sources/docoffic/official/repor_en.htm and http://ec.europa.eu/regional_policy/sources/docoffic/official/reports/cohesion4/index_en.htm (including main regional data).

Frank, A.G. (1967). Capitalism and Underdevelopment in Latin America: Historical Studies of Chile and Brazil. New York: Monthly Review Press.

------, (1998). ReOrient: Global Economy in the Asian Age. Ewing, U.S.A.: University of California Press.

Frankel, J.A. and Romer, D. (1999). "Does Trade Cause Growth?" American Economic Review, 89(3): 379-99. 
Furtado, C. (1983). Accumulation and Development: The Logic of Industrial Civilization. S. Macedo (trans.). Oxford: M. Robertson.

Galbraith, J.K. (1999). "Globalization and Pay," Proceedings of the American Philosophical Society, 143(2): 178-186.

-----, (2007). Maastricht 2042 and the Fate of Europe: Toward Convergence and Full Employment. International Policy Analysis Unit, Friedrich-Ebert-Stiftung.

------, (2009). "Inequality, Unemployment and Growth: New Measures for Old Controversies," The Journal of Economic Inequality, 7(2): 189-206.

Gallup, J.L. and Sachs, J.D., and Mellinger, A.D. (1999). "Geography and Economic Development," in B. Pleskovic and J.E. Stiglitz (eds.), Annual World Bank Conference on Development Economics (1998). Washington, D.C.: The World Bank (April). Also published in International Regional Science Review 22(2): 179-232.

Glasberg, D.S. and Ward, K.B. (1993). "Foreign Debt and Economic Growth in the World-System," Social Science Quarterly, 74(4): 703-720.

Grier, K.B. and Tullock, G. (1989). "An Empirical Analysis of Cross-national Economic Growth," Journal of Monetary Economics, 24(2): 259-76.

Guger, A.; Marterbauer, M., and Walterskirchen, E. (2004). "Growth Policy in the Spirit of Steindl and Kalecki," WIFO Working papers, 240. Available [online] at: http://ewald.walterskirchen.wifo.ac.at/

, (2006). "Zur Aktualität der Politischen Ökonomie von Josef Steindl," Kurswechsel, 4: 18-26. Available [online] at: http://ewald.walterskirchen.wifo.ac.at/ (no English translation available)

Gupta, V. (2000). Regression Explained in Simple Terms. Washington DC: A Vijai Gupta Publication. Available [online] at: http://stat2.med.up.pt/cursop/regressao/bibliografia/regression_explained_SPSS. doc

Gylfason, T. (2001). "Natural Resources, Education, and Economic Development," European Economic Review, 45 (4/6): 847-859

Hafner-Burton, E.M. (2005). "Right or Robust? The Sensitive Nature of Repression to Globalization," Journal of Peace Research, 42(6): 679-698.

Hall, R.E. and Jones, Ch.I. (1999). "Why Do Some Countries Produce so Much More Output per Worker than Others?" Quarterly Journal of Economics, 114(1): 83-116.

Hodler, R. (2004). The Curse of Natural Resources in Fractionalized Countries. Economics Department, University of Bern, Vereinsweg 23, CH-3012 Bern, Switzerland. Available [online] at: http://www. gsoep.de/documents/dokumentenarchiv/17/41536/Paper-132.pdf

Huntington, S.P. (1996). The Clash of Civilizations and the Remaking of World Order. New York: Simon and Schuster.

Inglehart, R.T. and Norris, P. (2003). Rising Tide: Gender Equality and Cultural Change around the World. New York: Cambridge University Press.

Jackman, R.W. (1982). "Dependence on Foreign Direct Investment and Economic Growth in the Third World," World Politics, 34(2): 175-196.

Jenkins, J.C. and Scanlan, S.J. (2001). "Food Security in Less Developed Countries, 1970 to 1990," American Sociological Review, 66(5): 718-744.

Jorgenson, A.K. (2004). "Global Inequality, Water Pollution, and Infant Mortality," The Social Science Journal, 41(2): 279-288. 
Jorgenson, A.K. (2009). "Foreign Direct Investment and the Environment, the Mitigating Influence of Institutional and Civil Society Factors, and Relationships between Industrial Pollution and Human Health," Organization and Environment, 22(2): 135-157.

Jorgenson, A.K. and Burns, T.J. (2004). "Globalization, the Environment, and Infant Mortality: A Cross National Study," Humboldt Journal of Social Relations, 28(1): 7-52.

Kalecki, M. (1971). Selected Essays on the Dynamics of the Capitalist Economy (1933-1970). Cambridge [Eng.]: Cambridge University Press.

Kamarck, A.M. (1976). The Tropics and Economic Development: A Provocative Inquiry into the Poverty of Nations. Baltimore: Johns Hopkins.

Kentor, J. (1998). "The Long-term Effects of Foreign Investment Dependence on Economic Growth, 1940-1990,” The American Journal of Sociology, 103(4): 1024-1046.

------, (2001). "The Long Term Effects of Globalization on Income Inequality, Population Growth, and Economic Development," Social Problems, Special Issue on Globalization and Social Problems, 48(4): 435-455.

Kentor, J. and Boswell, T. (2003). "Foreign Capital Dependence and Development: A New Direction," American Sociological Review, 68(2): 301-313.

Kentor, J. and Jorgenson, A.K. (2010). "Foreign Investment and Development. An Organizational Perspective," International Sociology, 25(3): 419-441.

Kentor, J. and Kick, D. (2008). "Bringing the Military Back in: Military Expenditures and Economic Growth 1990 to 2003," Journal of World-Systems Research, 14(2): 142-172, ISSN 1076-156X.

Kormendi, R.C. and Meguire, P. (1985). "Macroeconomic Determinants of Growth: Cross-country Evidence," Journal of Monetary Economics, 16(2): 141-163.

Kuznets, S. (1955). "Economic Growth and Income Inequality," The American Economic Review, 45(1): $1-28$.

Laver, M. and Shepsle, K.A. (1999). "Understanding Government Survival: Empirical Exploration or Analytical Models?" British Journal of Political Science, 29(2): 395-401.

Lee, Ch.-S. (2005). "Income Inequality, Democracy, and Public Sector Size," American Sociological Review, 70(1): 158-181.

Lee, Ch.-S., Nielsen, F., and Alderson, A.S. (2007). "Income Inequality, Global Economy and the State," Social Forces, 86(1): 77-111.

Lee, K. (2009). "Towards a Reformulation of Core/Periphery Relationship: A Critical Reappraisal of the Trimodality of the Capitalist World-economy in the Early 21 st Century," Perspectives on Global Development and Technology, 8(2/3): 263-294.

Levine, R.E. and Renelt, D. (1992). "Sensitivity Analysis of Cross-country Growth Regressions," The American Economic Review, 82(4): 942-963.

Li, Q. and Resnick, A. (2003). "Reversal of Fortunes: Democratic Institutions and Foreign Direct Investment Inflows to Developing Countries," International Organization, 57(1): 175-211.

London, B. and Ross, R.J.S. (1995). "The Political Sociology of Foreign Direct Investment - Global Capitalism and Capital Mobility, 1965-1980," International Journal of Comparative Sociology, 36(3/4): 198-218.

Mahutga, M.C. (2006). "The Persistence of Structural Inequality? A Network Analysis of International Trade, 1965-2000,” Social Forces, 84(4): 1863-1889. 
Mahutga, M.C. and Bandelji, N. (2008). "Foreign Investment and Income Inequality: The Natural Experiment of Central and Eastern Europe," International Journal of Comparative Sociology, 49(6): 429-454.

Mankiw, N.G., Romer, D., and Weil, D.N. (1992). "A Contribution to the Empirics of Economic Growth," Quarterly Journal of Economics, 107(2): 407-437.

Marterbauer, M. and Walterskirchen, E. (2006). Neglecting Demand and Cycle in the Euro Area. Vienna: Austrian Institute for Economic Research, WIFO Working Papers, No. 268, March. Available [online] at: http://ewald.walterskirchen.wifo.ac.at/

Meyer, L.B. (2003). "Economic Globalization and Women's Status in the Labor Market: A Crossnational Investigation of Occupational Sex Segregation and Inequality," The Sociological Quarterly, 44(3): 351-383).

Moore, S., Teixeira, A.C., and Shiell, A. (2006). "The Health of Nations in a Global Context: Trade, Global Stratification, and Infant Mortality Rates," Social Science and Medicine, 63(1): 165-178.

Moran, T. (2005). "Kuznets's Inverted U-Curve Hypothesis: The Rise, Demise, and Continued Relevance of a Socioeconomic Law," Sociological Forum, 20(2): 209-244.

Morris, T.M. (1999). "The Global Economy and Changes in the Determinants of Cross-national Income Inequality," Social Thought and Research, 22: 183-214.

Mostafa, M.M. (2010a). "A Bayesian Approach to Analyzing the Ecological Footprint of 140 Nations," Ecological Indicators, 10(4): 808-817.

-----, (2010b). “Clustering the Ecological Footprint of Nations using Kohonen's Self-organizing Maps," Expert Systems with Applications, 37(4): 2747-2755.

Mostafa, M.M. and Nataraajan, R. (2009). "A Neuro-computational Intelligence Analysis of the Ecological Footprint of Nations," Computational Statistics and Data Analysis, 53(9): 3516-3531.

Myrdal, G. (1957). Economic Theory and Under-developed Regions. London: Duckworth.

Perroux, F. (1983). A New Concept of Development: Basic Tenets. London: Croom and Helm.

Polanyi, K. (1944/1957). The Great Transformation. The Political and Economic Origins of Our Time. Boston: Beacon Press

Prebisch, R. (1988). "Dependence, Development, and Interdependence," in G. Ranis and T.P. Schultz (eds.), The State of Development Economics: 31 Oxford, United Kingdom: Basil Blackwell.

Ragin, C.C. and Bradshaw, Y.W. (1992). "International Economic Dependence and Human Misery, (1938-1980): A Global Perspective," Sociological Perspectives, 35(2): 217-247.

Reuveny, R. and Li, Q. (2003). "Economic Openness, Democracy, and Income Inequality: An Empirical Analysis," Comparative Political Studies, 36(5): 575-601.

Reuveny, R. and Thompson, W.W. (2004). "World Economic Growth, Systemic Leadership, and Southern Debt Crises," Journal of Peace Research, 41(1): 5-24.

Richards, D.L., Gelleny, R.D., and Sacko, D.H. (2001). "Money with a Mean Streak? Foreign Economic Penetration and Government Respect for Human Rights in Developing Countries," International Studies Quarterly, 45(2): 219-239.

Rodriguez, F. and Rodrik, D. (2001). "Trade Policy and Economic Growth: A Sceptic's Guide to the Cross-national Evidence,” NBER Working Paper No. 7081, issued in April 1999, NBER Program(s): ITI, available at http://www.nber.org/papers/w7081 
Rosenstein-Rodan, P.N. (1964). Capital Formation and Economic Development. London: Allen and Unwin.

Rothschild, K.W. (1995). Economic Method, Theory and Policy: Selected Essays of Kurt W. Rothschild. J.E. King (ed.). Aldershot, Hants, UK; Brookfield, VT: E. Elgar Pub.

Sachs, J.D. and Warner, A.M. (2001). “The Curse of Natural Resources,” European Economic Review, 45(4/6): 827-838.

Sala-i-Martin X., Doppelhofer, G., and Miller, R.I. (2004). "Determinants of Long-term Growth: A Bayesian Averaging of Classical Estimates (BACE) Approach," American Economic Review, 94(4): 813-835.

Sala-i-Martin, X. (1997). "I Just Ran Two Million Regressions," The American Economic Review, Papers and Proceedings of the Hundred and Fourth Annual Meeting of the American Economic Association, May, 87(2): 178-183.

Sanderson, M.R. (2010). "International Migration and Human Development in Destination Countries: A Cross-national Analysis of Less-developed Countries, 1970-2005," Social Indicators' Research, 96(1): 59-83.

------, (2013). "Does Immigration Promote Long-term Economic Development? A Global and Regional Cross-national Analysis, 1965-2005," Journal of Ethnic and Migration Studies, 39(1): 1-30, DOI: $10.1080 / 1369183 X .2013 .723244$

Sanderson, M.R. and Kentor, J. (2008). "Foreign Direct Investment and International Migration: A Cross-national Analysis of Less-developed Countries, 1985-2000," International Sociology, 23(4): 514-539.

-----. (2009). "Globalization, Development and International Migration: A Cross-national Analysis of Less-developed Countries, 1970-2000," Social Forces, 88(1): 301-336.

Seers, D. (ed.) (1981). Dependency Theory: A Critical Reassessment. London: Pinter.

Shandra, J.M. (2007). "Economic Dependency, Repression, and Deforestation: A Quantitative, Crossnational Analysis. Sociological Inquiry, 77(4): 543-571.

-----, (2007). "International Nongovernmental Organizations and Deforestation: Good, Bad, or Irrelevant?" Social Science Quarterly, 88(3): 665-689.

Shandra, J.M., Leckband, C., and London, B. (2009). "Ecologically Unequal Exchange and Deforestation: A Cross-national Analysis of Forestry Export Flows," Organization and Environment, 22(2): 208-229.

Shandra, J.M., Leckband, C., McKinney, L.A., and London, B. (2009). "Ecologically Unequal Exchange, World Polity, and Biodiversity Loss A Cross-National Analysis of Threatened Mammals," International Journal of Comparative Sociology, 50(3/4): 285-310.

Shandra, J.M., London, B., Whooley, O.P., and Williamson, J.B. (2004). "International Nongovernmental Organizations and Carbon Dioxide Emissions in the Developing World: A Quantitative, Cross-national Analysis," Sociological Inquiry, 74(4): 520-545.

Shandra, J.M., London, B., and Williamson, J.B. (2003). "Environmental Degradation, Environmental Sustainability, and Overurbanization in the Developing World: A Quantitative, Cross-national Analysis," Sociological Perspectives, 46(3): 309-329.

Shandra, J.M., Nobles, J., London, B., and Williamson, J.B. (2004). "Dependency, Democracy, and Infant Mortality: A Quantitative, Cross-National Analysis of Less-developed Countries," Social Science and Medicine, 59(2): 321-333. 
, (2005). "Multinational Corporations, Democracy and Child Mortality: A Quantitative, Crossnational Analysis of Developing Countries," Social Indicators Research, 73(2): 267-293.

Shandra, J.M., Shandra, C.L., and London, B. (2008). "Women, Nongovernmental Organizations, and Deforestation: a Cross-national Study," Population and Environment, 30(1/2): 48-72.

------, (2010). "Do Nongovernmental Organizations Impact Health? A Cross-national Analysis of Infant Mortality," International Journal of Comparative Sociology, 51(1/2): 137-164.

Shandra, J.M., Shor, E., and London, B. (2009). "World Polity, Unequal Ecological Exchange, and Organic Water Pollution: A Cross-national Analysis of Developing Nations," Human Ecology Review, 16(1): 53-63.

----. (2008). "Debt, Structural Adjustment, and Organic Water Pollution," Organization and Environment, 21(1): 38-55.

Shaw J.W., Hoorace, W.C., and Vogel, R.J. (2005). "The Determinants of Life Expectancy: An Analysis of the OECD Health Data," Southern Economic Journal, 71(4): 768-783.

Shen, C. and Williamson, J.B. (1997). "Child Mortality, Women's Status, Economic Dependency, and State Strength: A Cross-national Study of Less-developed Countries," Social Forces, 76(2): 667-700.

------, (1999). "Maternal Mortality, Women's Status, and Economic Dependency in Less-developed Countries: A Cross-national Analysis," Social Science and Medicine, 49(2): (197-214.

------, (2001). “Accounting for Cross-national Differences in Infant Mortality Decline 1965-1991 among Less-developed Countries: Effects of Women's Status, Economic Dependency, and State Strength," Social Indicators Research, 53(3): 257-288.

Singer, H.W. (1975). The Strategy of International Development: Essays in the Economics of Backwardness, A. Cairncross and M. Puri (eds.). London: Macmillan.

Spencer, M. (2006). "Peripherality, Income Inequality, and Life Expectancy: Revisiting the Income Inequality Hypothesis," International Journal of Epidemiology, 35(3): 623-632.

SPSS (2012). Statistical Package for the Social Sciences, User Guide, Version 20, August 2012.

Steindl, J. (1952). Maturity and Stagnation in American Capitalism. Oxford: Basil Blackwell.

Steindl, J. (1979). "Stagnation Theory and Stagnation Policy," Cambridge Journal of Economics, (3): $1-14$.

------, (1988). "Diskussionsbeitrag zur EG-Frage” Kurswechsel, 4(3): 3-7.

------, (1990). Economic Papers (1941-88). Basingstoke: MacMillan.

Sturm, J.-E. and de Haan, J. (2005). Determinants of Long-term Growth: New Results Applying Robust Estimation and Extreme Bounds. Research Paper Series, 12. Thurgauer Wirtschaftsinstitut, Constance University, FRG. Available [online] at:

http://www.kops.ub.uni-konstanz.de/volltexte/2005/1675/pdf/TWI_res12.pdf; later also published in Empirical Economics, 30(3): 597-617.

Sumner, A. (2005). "Is Foreign Direct Investment Good for the Poor? A Review and Stocktake," Development in Practice, 15(3/4): 269-285.

Tausch A. and Heshmati A. (2012). "Migration, Openness and the Global Preconditions of 'Smart Development'," Boğaziçi Journal. Review of Social, Economic and Administrative Studies, 26(2): 1-62. 
Tausch, A. and Ghymers, Chr. (2007). From the Washington towards a Vienna Consensus? A Quantitative Analysis on Globalization, Development and Global Governance. Hauppauge, NY: Nova Science.

Tsai, M.-Ch. (1995). "Foreign Direct Investment and Income Inequality: Further Evidence," World Development, 23(3): 469-483.

------, (1998). “The States' Interest Seeking and Economic Stagnation in the Third World: Crossnational Evidence," The Sociological Quarterly, 39(1): 101-118.

------, (1999). "State Power, State Embeddedness, and National Development in Less- developed Countries: A Cross-national analysis," Studies in Comparative International Development, 33(4): 66-88.

------, (2006a). “Economic and Non-economic Determinants of Poverty in Developing Countries: Competing Theories and Empirical Evidence," Canadian Journal of Development Studies/Revue Canadienne Detudes du Developpement, 27(3): 267-285.

------, (2006b). "Macro-structural Determinants of Political Freedom in Developing Countries: A Cross-national Analysis," Social Indicators Research, 76(2): 317-340.

------, (2007). “Does Globalization Affect Human Well-being?" Social Indicators Research, 81(1): 103-126.

------, (1995). “Foreign Direct Investment and Income Inequality: Further Evidence," World Development, 23(3): 469-483.

------, (1998). "The States Interest Seeking and Economic Stagnation in the Third World: Cross-national Evidence," The Sociological Quarterly, 39(1): 101-118.

United Nations (current issues) United Nations Human Development Report. New York and Oxford: Oxford University Press.

United Nations Conference on Trade and Development (current issues), World Investment Report. New York and Geneva: United Nations.

Wallerstein, I. (2000). The Essential Wallerstein New York: The New Press.

Wilkinson, R.G. and Picket, K.E. (2006). "Income Inequality and Population Health: A Review and Explanation of the Evidence," Social Science and Medicine, 62(7): 1768-1784.

Williamson, J.A. (2002). Is Protection Bad for Growth? Will Globalization Last? Looking for Answers in History. Presented at the $13^{\text {th }}$ IEHA Congress, Buenos Aires, August 22-26, Draft Date: June (2002). Available [online] at: http://www.economics.harvard.edu/faculty/williamson/jwilliamworkingpapers

Wimberley, D.W. (1998). "Transnational Corporate Investment and Food in the Third World: A Cross-national Analysis,” Rural Sociology, 56(3). 406-431.

Wimberley, D.W. and Bello, R. (1992). "Effects of Foreign Investment, Exports and Economic Growth on Third World Food Consumption," Social Forces, 70(4): 895-921.

World Economic Forum (WEF) (2012). Global Gender Gap Report, (2012). Available [online] at: http://europa.eu/rapid/press-release_SPEECH-07-293_en.htm 


\section{Appendix 1:}

Multiple Stepwise Regressions - the Dependency Model, Tested against Feminist, Demographic, Neoliberal, Geographic, Cultural, Peace Research, Human Capital Policy Predictors, Migration Theories and Integration Theories

\section{Predictors:}

$\%$ women in government, all levels

$\%$ world population

2000 Economic Freedom Score

Absolute latitude

Annual population growth rate, 1975-2005\%)

Comparative price levels (US=1.00)

Foreign savings rate

FPZ (free production zones) employment as $\%$ of total population

Ln GDP per capita

Ln GDP per capita ${ }^{\wedge} 2$

Membership in the Islamic Cooperation

Military expenditures per GDP

Military personnel rate $\ln (\mathrm{MPR}+1)$

MNC outward investments (stock) per GDP

MNC PEN - stock of Inward FDI per GDP

MNC PEN: DYN MNC PEN 1995-2005

Openness-Index, 1990 (export-share per GDP + import-share per GDP)

Population density

Public education expenditure per GNP

UNDP education index

Worker remittance inflows as \% of GDP

Immigration - Share of population 2005 (\%)

Muslim population share per total population

Net international migration rate, 2005-2010

Years of membership in the EU, 2010

Years of membership in EMU, 2010

The reported equations were chosen from the following dependent variables:

1. Closing overall gender gap

2. Closing the political gender gap

3. Happy Life Years

4. Life Satisfaction (0-10)

5. Life expectancy (years)

6. Quintile share income difference between richest and poorest $20 \%$

7. Unemployment rate 


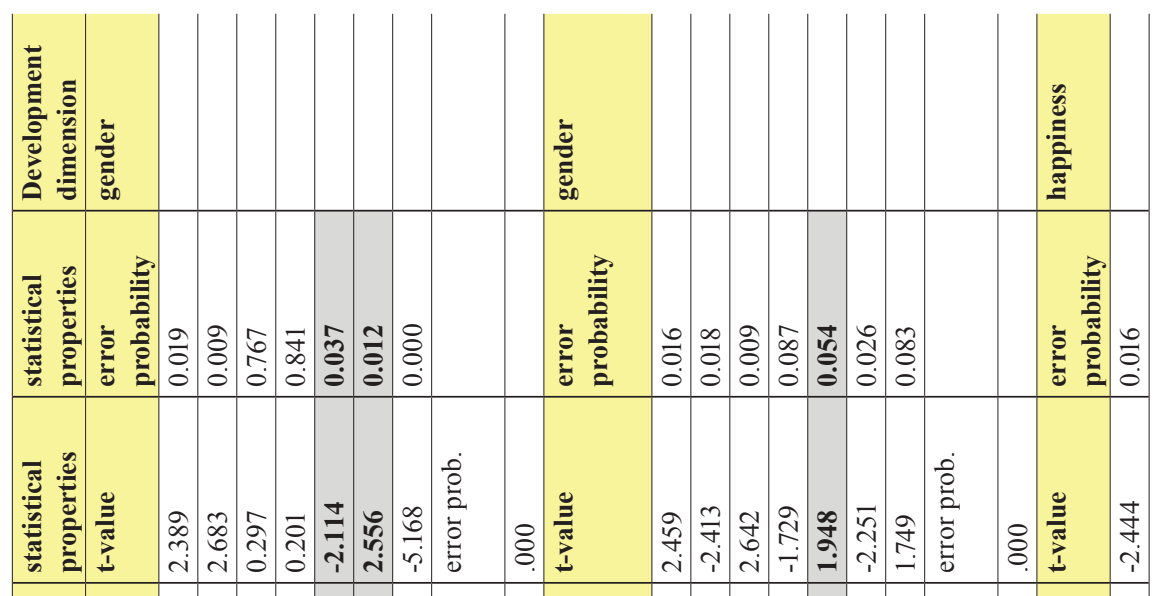

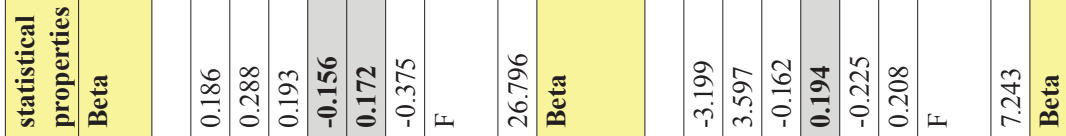

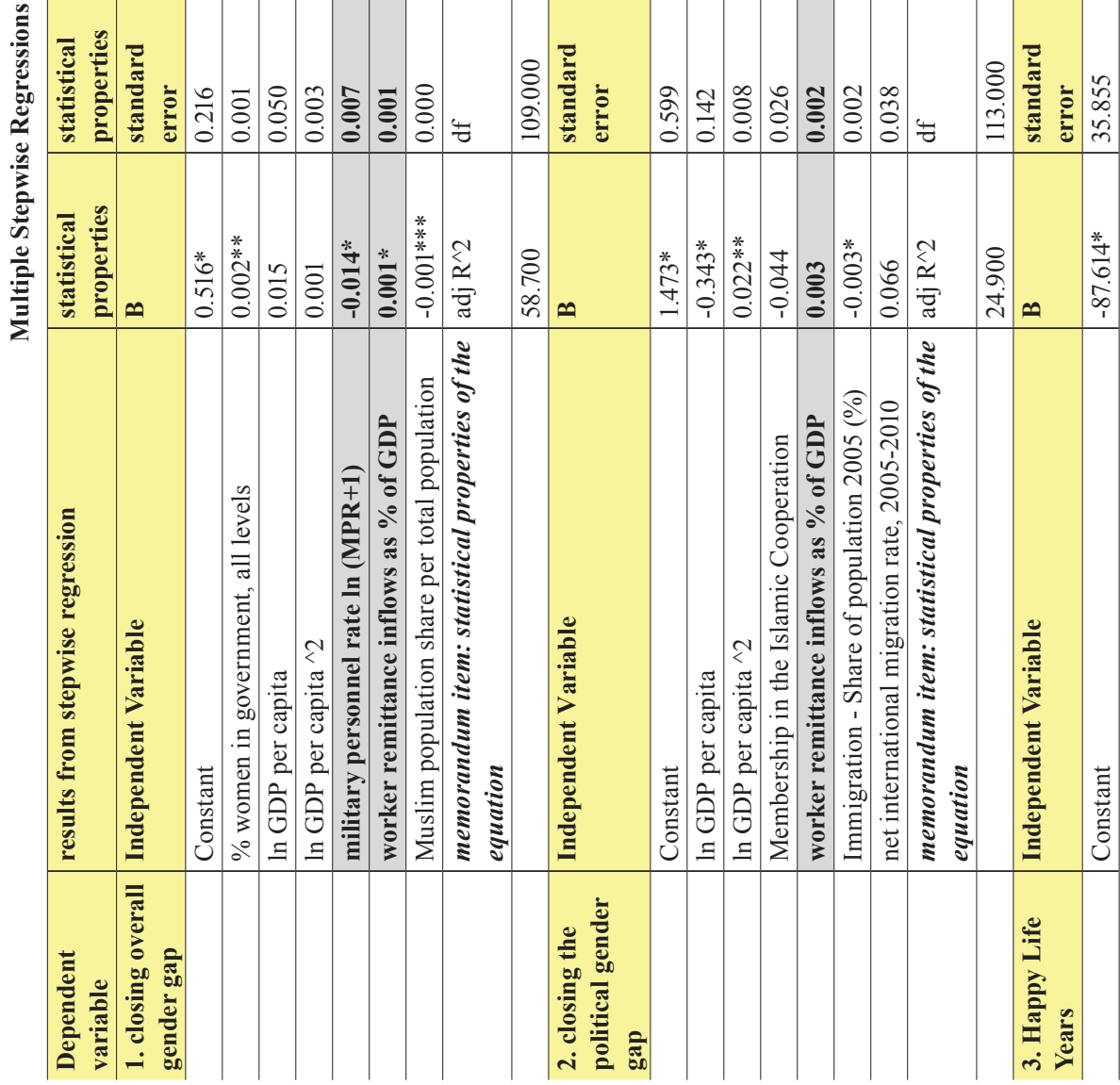




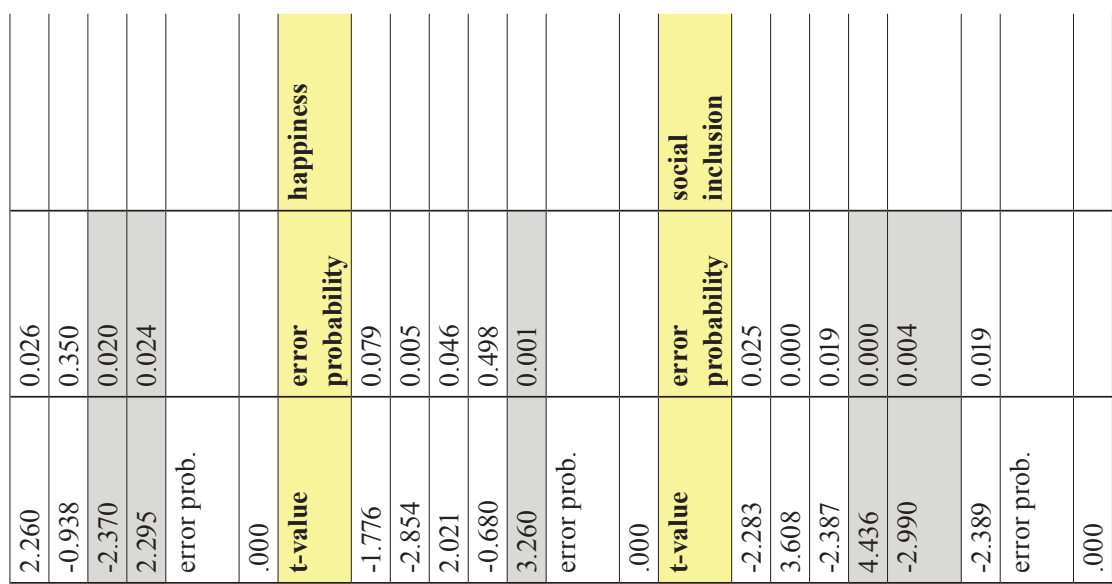

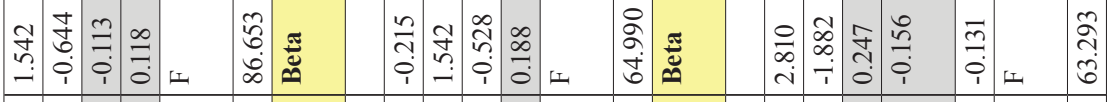

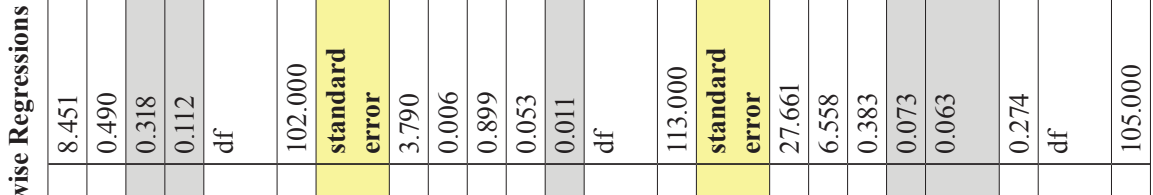

离

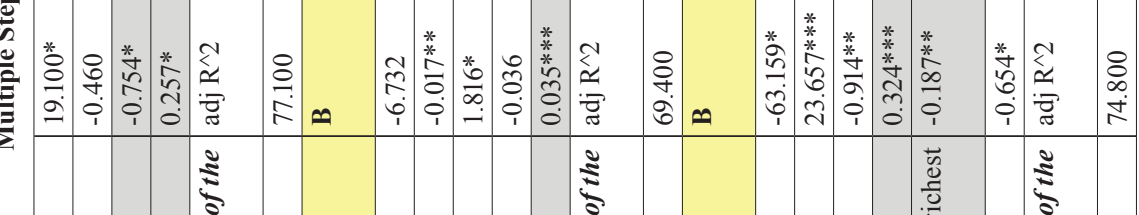

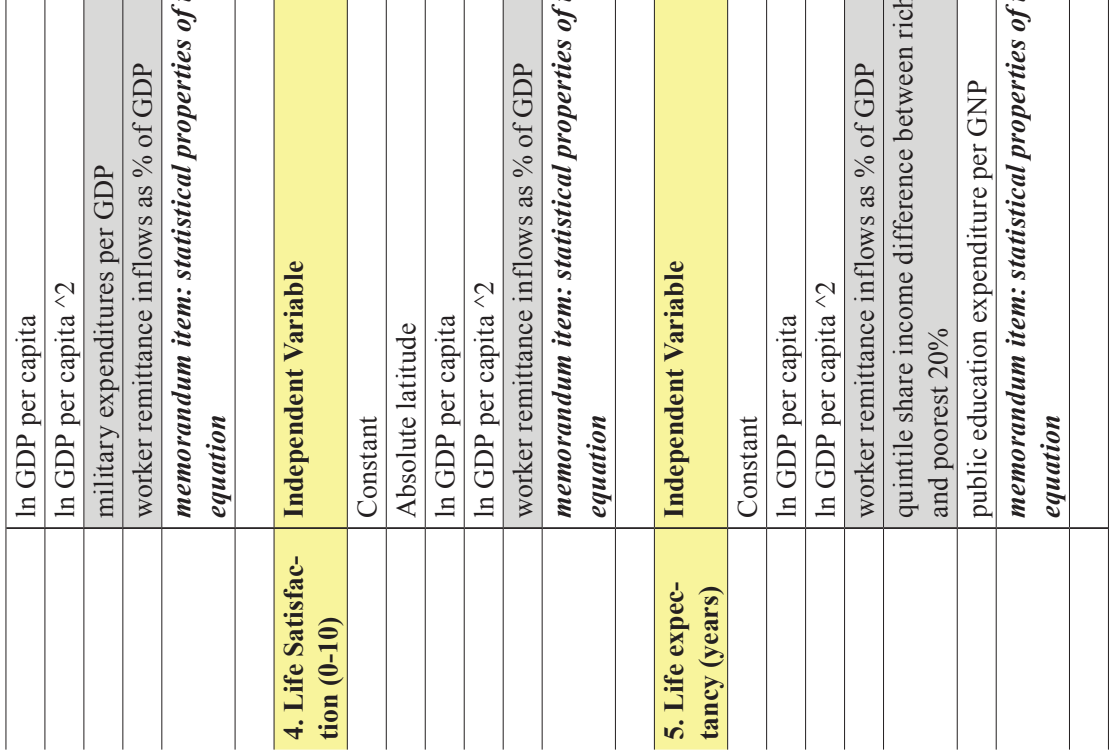




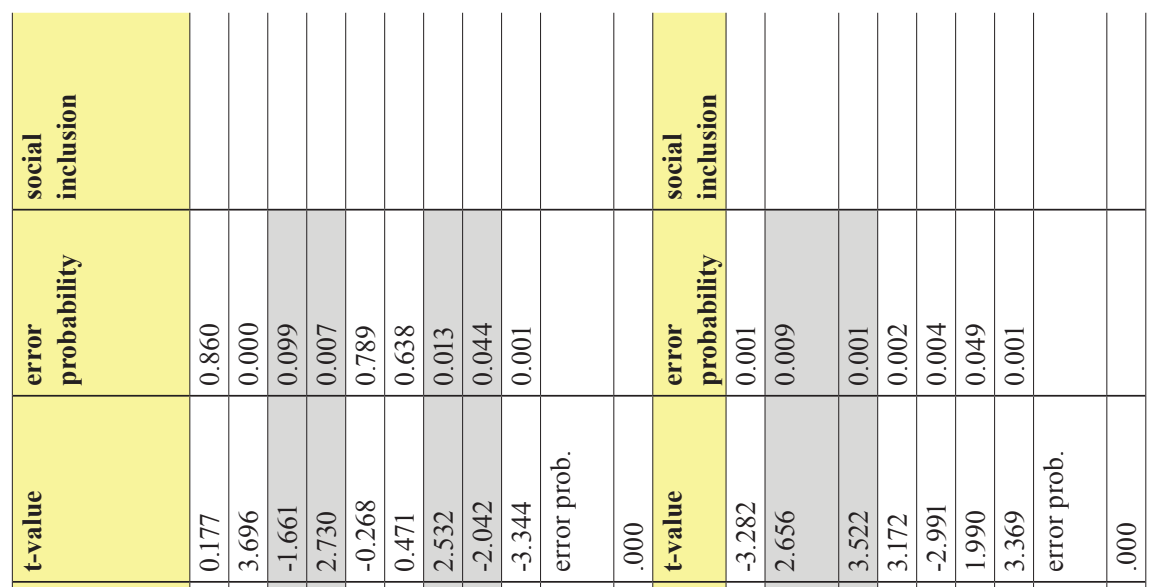

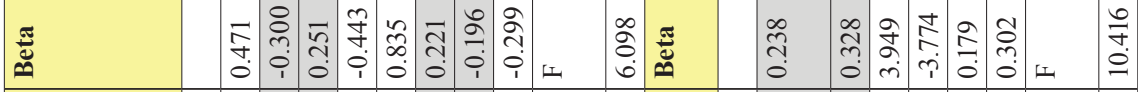

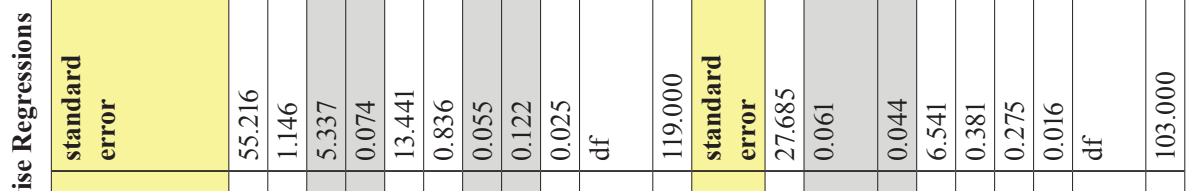

离

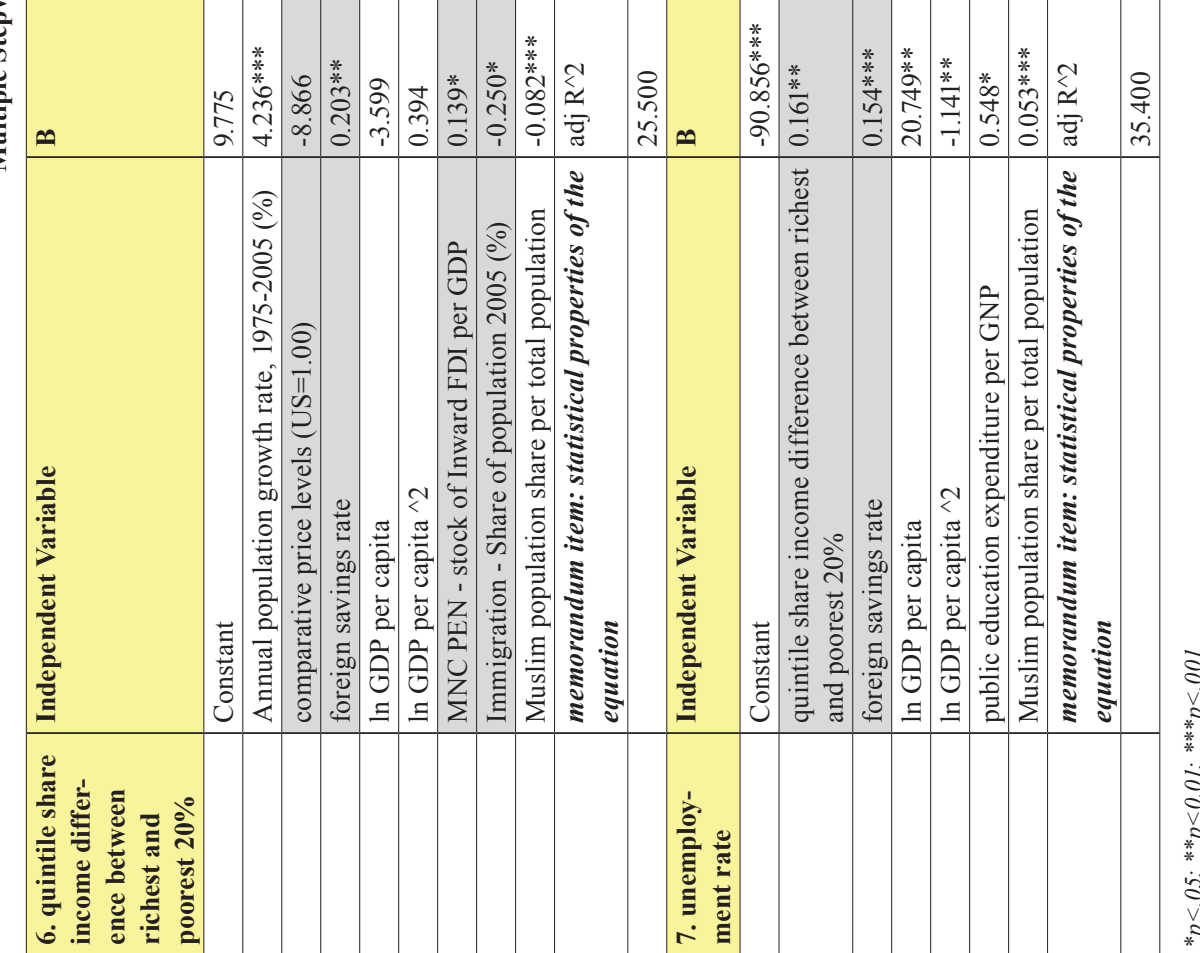




\section{Appendix 2:}

\section{The Sources for the Cross-national Data Collection}

All the variables are also contained in:

http://www.social-sciences-and-humanities.com/journal/?p=3402

This data set combines the most up-to-date data on the social, economic, political, and environmental effects of globalization. The dataset in EXCEL format is freely available; and also there is an SPSS XX version of the data freely available.

The data definitions and the codebook are to be downloaded freely at http://www. social-sciences-and-humanities.com/journal/wp-content/uploads/2010/10/Dataset-for-Globalization-the-human-condition-and-sustainable-development-inthe-21st-Century-Cross-national-perspectives-and-European-implications.pdf The EXCEL data file is available from: http://www.social-sciences-and-humanities.com/journal/?p=3402 (final data set) 
Appendix 3:

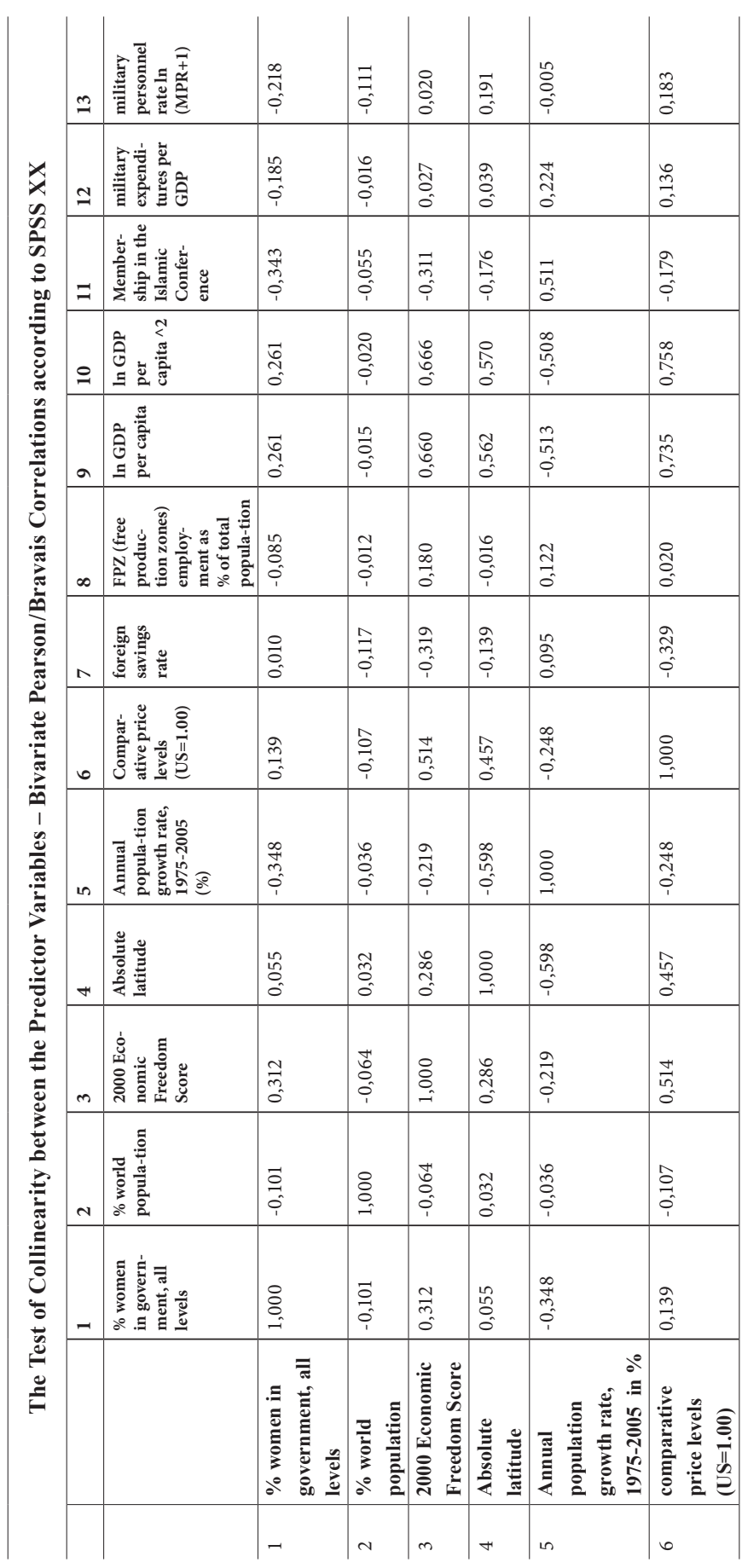




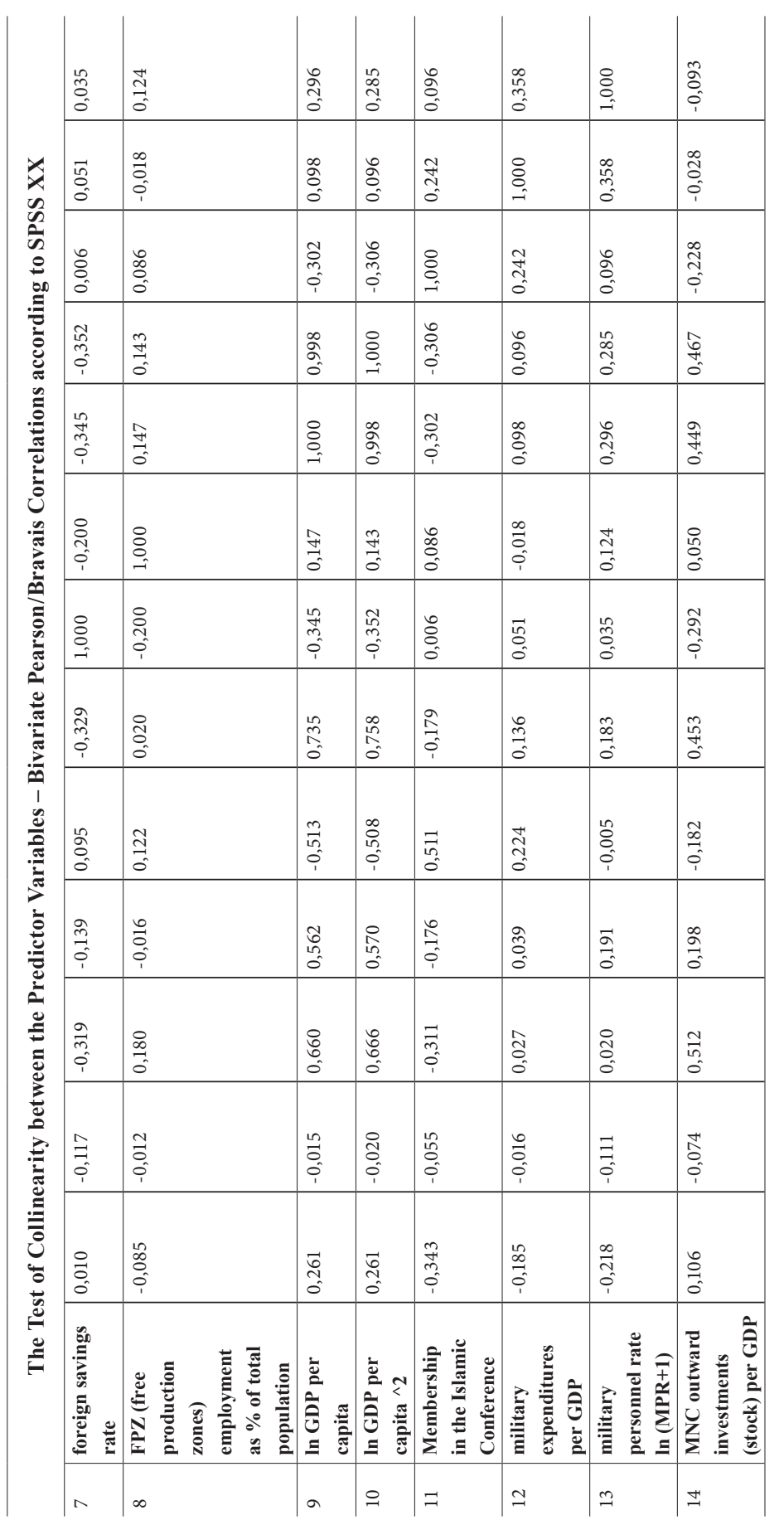

